\title{
Girdin protein: A potential metastasis predictor associated with prognosis in lung cancer
}

\author{
ZHAOYANG YANG ${ }^{1}$, FANG YANG $^{1}$, YINGLI ZHANG ${ }^{2}$, XIN WANG $^{1}$, \\ JIONG SHI ${ }^{3}$, HONGJIAO WEI ${ }^{1}$, FENGWEI SUN ${ }^{1}$ and YAN YU ${ }^{1}$ \\ ${ }^{1}$ Department of Medical Oncology, Harbin Medical University Cancer Hospital; \\ ${ }^{2}$ Department of Internal Medicine, Harbin Red Cross Center Hospital, Harbin, Heilongjiang 150081; \\ ${ }^{3}$ Department of Pathology, Nanjing Drum Tower Hospital, Nanjing, Jiangsu 210000, P.R. China
}

Received July 23, 2016; Accepted May 5, 2017

DOI: $10.3892 / e t m .2018 .5773$

\begin{abstract}
The present study explored the relationship between Girdin protein expression and the survival rate of patients with lung carcinoma. A total of 334 lung cancer specimens, 20 benign lung disease tissue sections and 24 fresh tissues from patients with lung carcinoma were analyzed by immunohistochemistry and western blotting. Girdin protein was expressed in 130/334 (38.93\%) of the cases examined. Girdin protein expression was correlated with tumor/node/metastasis stage $(\mathrm{P}<0.001)$, lymph node metastasis $(\mathrm{P}=0.001)$, distant metastasis $(\mathrm{P}<0.001)$ and specimen sites $(\mathrm{P}=0.034)$. Girdin expression was also correlated with signal transducer and activator of transcription 3 (STAT3) expression $(\mathrm{P}<0.001)$. Patients with high Girdin and STAT3 expression had a significantly poorer prognosis compared with those with low/high, high/low or low/low expression $(\mathrm{P}<0.001)$. In summary, Girdin may be a prognostic marker of lung cancer and serve as a biomarker for metastasis.
\end{abstract}

\section{Introduction}

According to the National Cancer Institute, although lung cancer mortality rates have declined due to reduced tobacco use, lung cancer remains the leading cause of cancer-related mortality worldwide (1). A high rate of metastasis at diagnosis is the principal reason for poor prognosis (2). Tumor invasion and metastasis are complex and dynamic processes controlled by multiple factors, including tumor cells and the tumor microenvironment (3). Lung cancer patients are prone to distant metastases; thus, the survival period is shortened

Correspondence to: Professor Yan Yu, Department of Medical Oncology, Harbin Medical University Cancer Hospital, 150 Haping Road, Harbin, Heilongjiang 150081, P.R. China

E-mail: 13946066560@163.com

Key words: lung cancer, immunohistochemistry, western blotting, Girdin, signal transducer and activator of transcription 3 and life quality is affected (4). Nevertheless, the mechanism of metastasis in lung cancer remains unclear.

The phosphoinositide 3-kinase-protein kinase B (Akt) signaling pathway is believed to be closely associated with metastasis (5). Girdin, an Akt substrate and newly discovered nuclear actin-binding protein, has a key role in promoting cell migration and angiogenesis during embryonic development, inflammation and tumor angiogenesis, and it is highly expressed in several human malignant carcinomas, such as colon, breast, glioblastoma and esophageal carcinomas (6-12). A study by Song et al (13) assessed Girdin expression and the correlation between its expression and clinical-pathological parameters and survival in a cohort of 36 consecutive patients with non-small cell lung cancer (NSCLC), and observed a significant correlation between elevated Girdin expression and blood vessel infiltration of the tumor.

The Janus kinase-signal transducer and activator of transcription (STAT) signaling pathway is also closely associated with many biological processes, particularly metastasis (14). The STAT family consists of six members (STAT1-STAT6), of which STAT3 is one of the most common sustained activated signaling proteins (15). A study by Dunkel et al (16) demonstrated that Girdin is capable of forming a positive feedback loop to increase the activity of STAT3, thereby promoting tumor invasion and migration. In a previous study, to explore whether Girdin is mediated by STAT3 in lung cancer, the authors of the present study depleted endogenous STAT3 and observed that Girdin expression decreased (17). It was also found that interleukin (IL)-17 promotes tumor angiogenesis in NSCLC by activating STAT3/Girdin signaling in NSCLC cell lines, which subsequently upregulates vascular endothelial growth factor (17). Nevertheless, few studies have explored the expression of Girdin protein and STAT3, as well as their relationship with lung cancer.

In the present study, the correlation between Girdin protein and STAT3 protein in lung cancer was evaluated using immunohistochemistry (IHC). A prognostic model based on clinical parameters was also generated to determine whether Girdin could act as a prognostic biomarker for lung cancer. 


\section{Patients and methods}

Patient tissue samples. A total of 334 NSCLC tissue sections, 20 benign lung disease tissue sections, 20 adjacent normal lung tissues sections, 24 fresh NSCLC tissues and 5 fresh normal lung tissue sections were obtained with informed consent at the Harbin Medical University Cancer Hospital (Harbin, China) between January 2005 and December 2006. All patients included in the present study had been surgically resected and diagnosed with stage I-IIIA NSCLC. Patients with any other types of cancer, or who missed follow-up appointments were excluded from the study. This retrospective analysis was approved by the Ethics Committee of Harbin Medical University Cancer Hospital. The clinical parameters extracted from medical records included: Age; sex; smoking history; Eastern Cooperative Oncology Group (ECOG) performance status (18); histological type and grade; stage (IASLC 7th TNM Staging system) (19); metastasis sites; diameter of the carcinoma; and specimen sites.

$I H C$. For IHC, 4- $\mu$ m-thick formaldehyde-fixed (fixed with $4 \%$ formaldehyde at room temperature for $24 \mathrm{~h}$ ), paraffin-embedded sections of 334 NSCLC, 20 benign lung disease and 20 adjacent normal lung tissues were deparaffinized in xylene and then rehydrated in serially graded alcohols. Antigens were retrieved by boiling the samples in $10 \mathrm{mM}$ sodium citrate buffer at $\mathrm{pH}$ 6.0 for $30 \mathrm{~min}$. Subsequently, the sections were washed with phosphate-buffered saline ( $\mathrm{pH}$ 7.4), blocked with $3 \%$ hydrogen peroxide at room temperature for $20 \mathrm{~min}$ and incubated overnight at $4^{\circ} \mathrm{C}$ with anti-Girdin (ab111035; 1:100; Abcam, Cambridge, UK) and anti-STAT3 (ab119352; 1:500; Abcam) antibodies. The slides were incubated with horseradish peroxidase-conjugated anti-rabbit immunoglobulin G secondary antibodies (SC2040, 1:400, Santa Cruz Biotechnology, Inc., Dallas, TX, USA) for $30 \mathrm{~min}$ at room temperature, followed by signal detection with diaminobenzidine. The slides were counterstained with hematoxylin at room temperature for $5 \mathrm{~min}$. The mean percentage of positive tumor cells was determined in at least five fields at magnification, x200 using a light microscope.

The slides were evaluated independently by two experienced pathologists who reached a consensus. The percentages of positive cells were categorized as follows: $0,0 \% ; 1,0-10 \%$; $2,10-50 \%$; and $3,>50 \%$. The staining intensity was scored as follows: 0 , negative; 1 , weak; 2 , moderate; and 3, strong. The scores for the percentage of positive cells and staining intensity were multiplied to achieve a weighted score for each case. Cases with scores $\leq 4$ were defined as low expression and cases with scores $>4$ were defined as high expression.

Western blot analysis. A total of 24 fresh NSCLC and 5 normal tissues were washed three times with PBS solution and treated by ultrasonic lysis with a radioimmunoprecipitation lysis buffer (P0013C; Beyotime Institute of Biotechnology, Haimen, China) for protein extraction. Protein were quantified by BCA. A total of $30 \mu \mathrm{g}$ of protein were loaded per lane and separated by $10 \%$ SDS-PAGE, after which the proteins were transferred to a polyvinylidene difluoride membrane. Subsequently, the membrane was blocked with 5\% skim milk for $1 \mathrm{~h}$ at room temperature and incubated with primary antibodies directed against Girdin, (ab113890; 1:500; Abcam) and $\beta$-actin (4970P;
Table I. Correlation between Girdin and STAT3 expression in non-small cell lung cancer tissues.

\begin{tabular}{lrrrrr}
\hline & \multicolumn{2}{c}{ Girdin } & & \\
\cline { 2 - 3 } Transcription factor & High & Low & & & P-value \\
\hline STAT3 & 110 & 29 & 0.696 & $<0.001$ \\
High & 20 & 175 & & \\
Low & & & & & \\
\hline
\end{tabular}

STAT3, signal transducer and activator of transcription 3.

1:1,000; CST Biological Reagents Co., Ltd., Shanghai, China) overnight at $4^{\circ} \mathrm{C}$. Appropriately diluted specific secondary antibodies (anti-rabbit IgG; ZB2301; 1:1,000; OriGene Technologies, Inc., Beijing, China) were added and incubated for $1 \mathrm{~h}$ at room temperature. An enhanced chemiluminescence kit (Pierce; Thermo Fisher Scientific, Inc., Waltham, MA, USA) was used to detect and analyze immunostained protein bands using a charge-coupled camera (LAS4000; Fujifilm, Tokyo, Japan) and Gel-Pro Analyzer software version 4.0 (Media Cybernetics, Inc., Rockville, MD, USA).

Statistical analysis. Data were presented as the mean \pm standard deviation. Statistical analysis was performed using SPSS 18.0 software (SPSS, Inc., Chicago, IL, USA). $\mathrm{P}<0.05$ was considered to indicate a statistically significant difference. ANOVA and Dunnett's post hoc test was performed for the comparison of Girdin expression between fresh tumor and normal tissues. A multivariate Cox regression model was used to analyze prognostic variables for survival measures. Chi-squared tests were used to examine the statistical association between clinical-pathological and IHC data. Survival curves were plotted using the Kaplan-Meier method and differences were assessed using the log-rank test. The correlation between Girdin and STAT3 was calculated using Spearman's rank correlation coefficient.

\section{Results}

Patient characteristics. To evaluate the clinical significance of Girdin expression in NSCLC, an IHC analysis of 334 NSCLC tissues samples, 20 benign lung disease tissues (pulmonary hamartoma, pulmonary fibroma, pulmonary hemangioma and pneumonia) and 20 adjacent normal lung tissues was performed. The mean age of the 334 NSCLC patients enrolled in the present study was 50.87 years (range, $29-80$ years). Of these, 178/334 (53.23\%) patients had lymph node metastasis and 82/334 (24.53\%) exhibited distant metastasis (Table I).

Expression and localization of Girdin and STAT3 in NSCLC, benign lung disease and normal lung tissues. As demonstrated in Fig. 1, cytoplasmic and membrane Girdin immunoreactivity was detected in 130/334 lung cancer samples $(38.93 \%)$ and $10 \%$ (2/20, one pulmonary hamartoma and one pulmonary hemangioma) of benign cases, whereas it was not present in the adjacent normal tissues $(0 / 20)$. STAT3 

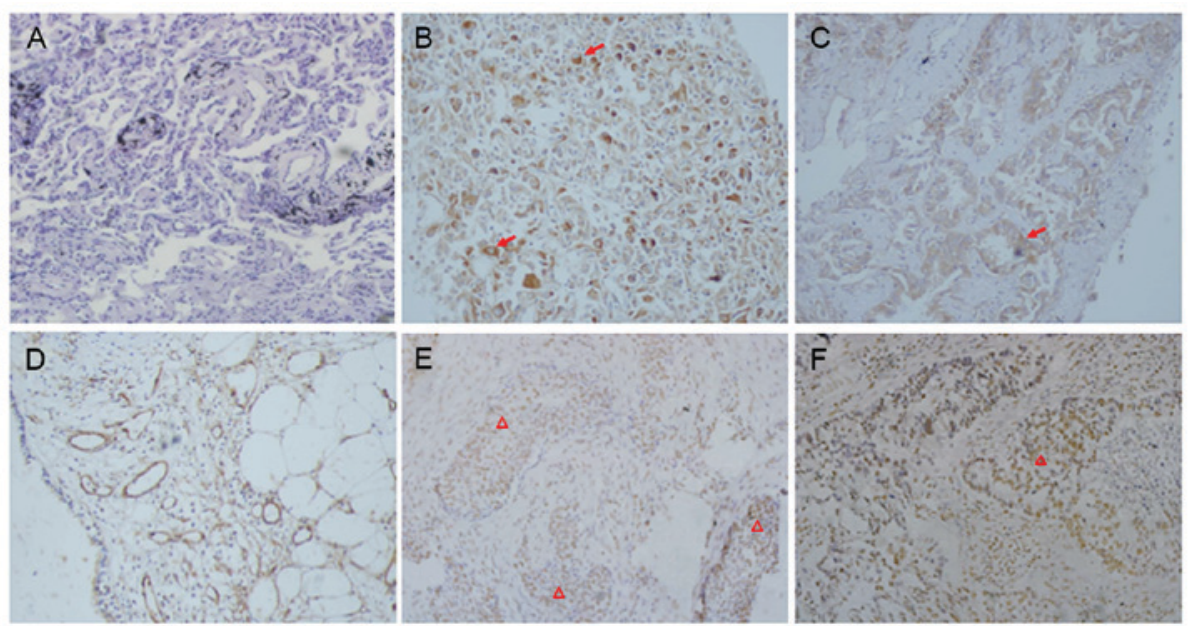

Figure 1. Immunohistochemical staining of Girdin and STAT3 in non-small cell lung cancer, benign lung disease and normal lung tissues (magnification, x200;). (A) Negative staining of Girdin in normal lung tissues. (B) Positive staining of Girdin in lung squamous cell carcinoma. (C) Positive staining of Girdin in lung adenocarcinoma. (D) Positive staining of Girdin in pulmonary hamartoma. (E) Positive staining of STAT3 in lung squamous cell carcinoma. (F) Positive staining of STAT3 in lung adenocarcinoma. Red arrows indicate examples of cytoplasmic and membrane staining; red triangles indicate examples of nucleic staining. STAT3, signal transducer and activator of transcription 3.

was predominately localized in the nuclei of tumor cells. Western blotting was used to investigate Girdin expression in fresh tumor tissues and normal tissues (Fig. 2). Girdin expression was significantly higher in several NSCLC tissue samples compared with normal tissues as determined by one-way ANOVA ( $\mathrm{P}<0.05$; Fig. 2).

The potential correlation between the expression of Girdin and STAT3 in NSCLC was assessed. Spearman's rank correlation analysis revealed that Girdin expression was closely correlated with STAT3 expression in the NSCLC patient cohort $(r=0.696 ; \mathrm{P}<0.001)$ (Table I).

Relationship between Girdin and STAT3 overexpression and clinical-pathological parameters. The correlations between Girdin and STAT3 expression and the clinicopathological characteristics of NSCLC are demonstrated in Table II. Lung tumor expression of Girdin was not dependent on age, sex, smoking history, family history, histology, ECOG performance status, histopathological subtype, degree of differentiation, tumor size, metastatic site or T stage. Lung tumor expression of STAT3 in the lung cancer cases was not dependent on age, sex, smoking history, family history, histology, ECOG performance status, histopathological subtype, degree of differentiation or specimen sites. Elevated expression of Girdin was associated with positive lymph node metastasis status $(\mathrm{P}=0.001)$, positive distant metastasis status $(\mathrm{P}<0.001)$, later TNM stage $(\mathrm{P}<0.001)$ and more tumor sites $(\mathrm{P}=0.034)$. Elevated expression of STAT3 was correlated with later TNM stage $(\mathrm{P}=0.007)$, positive lymph node metastasis status $(\mathrm{P}<0.001)$, positive distant metastasis $(\mathrm{P}=0.011)$, later $\mathrm{T}$ stage $(\mathrm{P}=0.004)$ and larger tumor diameter $(\mathrm{P}=0.002)$.

Elevated Girdin and STAT3 expression is associated with poor prognosis in NSCLC. The Kaplan-Meier survival curves of Girdin and STAT3 for overall survival (OS) and progression-free survival (PFS) are demonstrated in Fig. 3. Patients with elevated Girdin expression were observed to have significantly shorter OS $(\mathrm{P}<0.001)$ and PFS $(\mathrm{P}<0.001)$

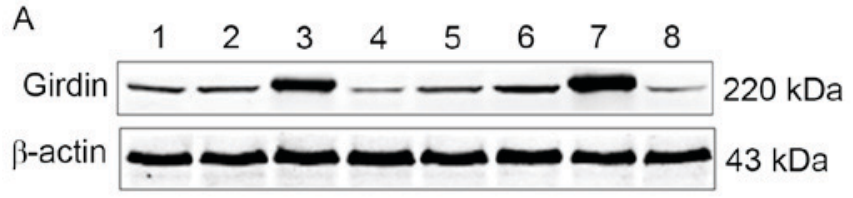

B

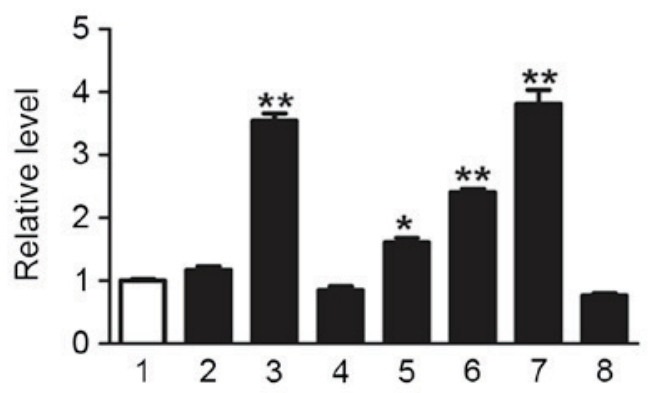

Figure 2. Western blot analysis of Girdin in non-small cell lung cancer and normal lung tissues. (A) Western blot analysis in representative samples of NSCLC and normal tissues and (B) densitometry analysis of protein expression relative to normal tissue. 1, normal tissue; 2-8, NSCLC tissues. Girdin expression was significantly higher in several NSCLC tissue samples $(3,5,6$ and 7) compared with normal tissues. ${ }^{*} \mathrm{P}<0.01$ and ${ }^{* *} \mathrm{P}<0.001$ vs. normal tissue.

compared with those with lower expression. Patients with increased STAT3 expression were observed to have significant shorter OS $(\mathrm{P}<0.001)$ and PFS $(\mathrm{P}<0.001)$ rates compared with patients with low-level expression. Furthermore, patients with low expression of both Girdin and STAT3 were observed to have significantly longer OS $(\mathrm{P}<0.001)$ and PFS $(\mathrm{P}<0.001)$ compared with individuals with high/high expression and others (low/high, high/low) expression (Fig. 4).

Elevated Girdin expression is independently associated with $O S$ and PFS in NSCLC. To identify prognostic variables of NSCLC, a multivariate analysis was performed. It was 
Table II. Association between Girdin, STAT3 and clinicopathological factors in non-small cell lung cancer ( $\mathrm{n}=334)$.

\begin{tabular}{|c|c|c|c|c|c|c|}
\hline \multirow[b]{2}{*}{ Parameter } & \multicolumn{2}{|c|}{ Girdin expression } & \multirow[b]{2}{*}{ P-value } & \multicolumn{2}{|c|}{ STAT3 expression } & \multirow[b]{2}{*}{ P-value } \\
\hline & Low & High & & Low & High & \\
\hline Age, years & & & 0.625 & & & 0.822 \\
\hline$<55$ & 68 & 40 & & 64 & 44 & \\
\hline$\geq 55$ & 136 & 90 & & 131 & 95 & \\
\hline Gender & & & 0.508 & & & 0.223 \\
\hline Male & 142 & 86 & & 128 & 100 & \\
\hline Female & 62 & 44 & & 67 & 39 & \\
\hline Family history & & & 0.448 & & & 0.094 \\
\hline Yes & 40 & 30 & & 47 & 23 & \\
\hline No & 164 & 100 & & 148 & 116 & \\
\hline Smoking status & & & 0.473 & & & 0.616 \\
\hline Non-smoker & 118 & 70 & & 112 & 76 & \\
\hline Smoker & 86 & 60 & & 83 & 63 & \\
\hline ECOG status & & & 0.799 & & & 0.158 \\
\hline $0-1$ & 190 & 122 & & 179 & 133 & \\
\hline$\geq 2$ & 14 & 8 & & 16 & 6 & \\
\hline Histology grade & & & 0.104 & & & 0.633 \\
\hline Well-differentiated & 2 & 2 & & 2 & 2 & \\
\hline Moderately differentiated & 62 & 26 & & 55 & 33 & \\
\hline Poorly differentiated & 140 & 102 & & 138 & 104 & \\
\hline Histological type & & & 0.496 & & & 0.764 \\
\hline Adenocarcinoma & 106 & 64 & & 96 & 74 & \\
\hline Squamous cell carcinoma & 80 & 58 & & 83 & 55 & \\
\hline Other & 18 & 8 & & 16 & 10 & \\
\hline TNM stage & & & $<0.001$ & & & 0.007 \\
\hline I-IIIA & 150 & 56 & & 132 & 74 & \\
\hline IIIB-IV & 54 & 74 & & 63 & 65 & \\
\hline Tumor stage & & & 0.693 & & & 0.004 \\
\hline $\mathrm{T} 1$ & 44 & 26 & & 48 & 22 & \\
\hline $\mathrm{T} 2$ & 114 & 72 & & 108 & 78 & \\
\hline $\mathrm{T} 3$ & 26 & 22 & & 18 & 30 & \\
\hline $\mathrm{T} 4$ & 20 & 10 & & 21 & 9 & \\
\hline Lymph node metastasis & & & 0.001 & & & $<0.001$ \\
\hline Yes & 94 & 84 & & 88 & 90 & \\
\hline No & 110 & 46 & & 107 & 49 & \\
\hline Distant metastasis & & & $<0.001$ & & & 0.011 \\
\hline Yes & 26 & 56 & & 38 & 44 & \\
\hline No & 178 & 74 & & 157 & 95 & \\
\hline Diameter of tumor, $\mathrm{cm}$ & & & 0.434 & & & 0.002 \\
\hline$\leq 3$ & 58 & 32 & & 64 & 26 & \\
\hline $3-7$ & 134 & 86 & & 123 & 97 & \\
\hline$>7$ & 12 & 12 & & 8 & 16 & \\
\hline Sites of specimen & & & 0.034 & & & 0.797 \\
\hline Primary tumor site & 190 & 112 & & 177 & 125 & \\
\hline Metastasis tumor site & 14 & 18 & & 18 & 14 & \\
\hline
\end{tabular}

ECOG, Eastern Cooperative Oncology Group; TNM, tumor/node/metastasis; STAT3, signal transducer and activator of transcription 3. 
A

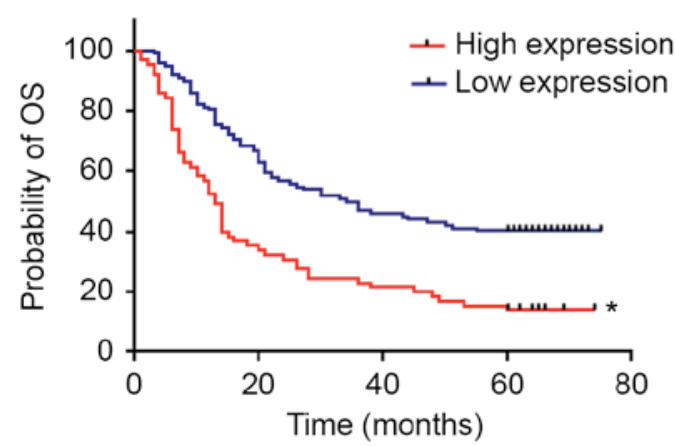

C

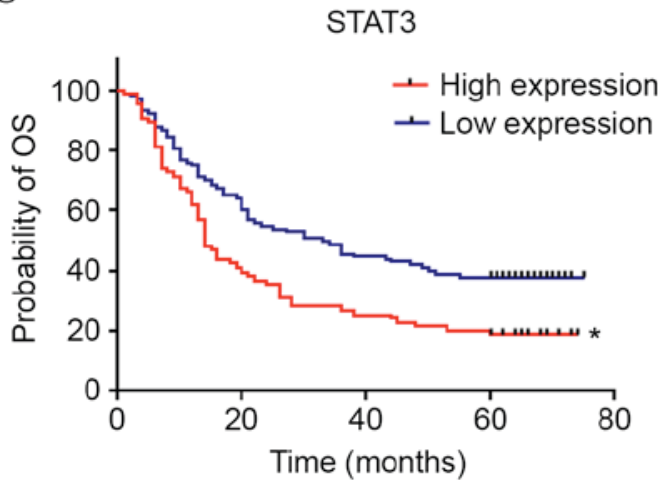

B

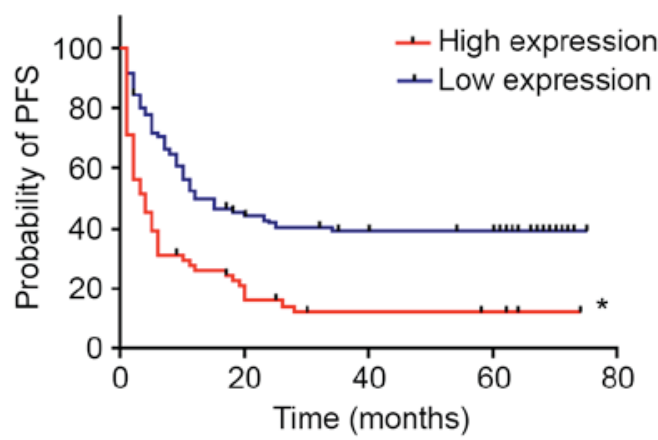

D

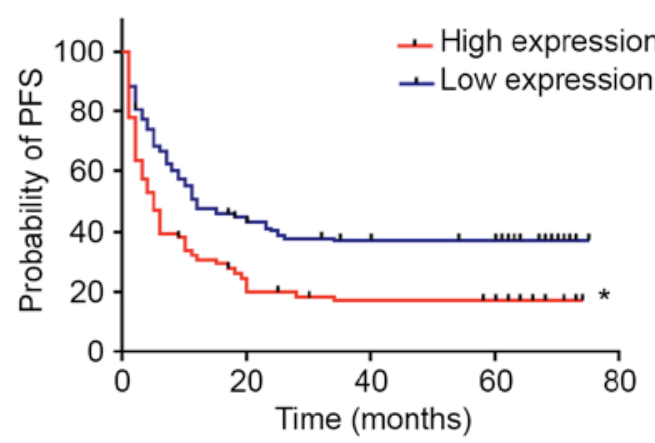

Figure 3. Kaplan-Meier survival curves of Girdin and STAT3 expression for OS and PFS in patients with non-small cell lung cancer. Patients with high Girdin expression were observed to have poorer (A) median OS (13 vs. 35 months) and (B) median PFS (4 vs. 12 months) compared with those with lower expression. Patients with high STAT3 expression were observed to have poorer (C) median OS (14 vs. 33 months) and (D) median PFS (5 vs. 12 months) compared with those with lower expression. * $\mathrm{P}<0.001$ vs. low expression. OS, overall survival; PFS, progression-free survival; STAT3, signal transducer and activator of transcription 3 .

A

Girdin and STAT3

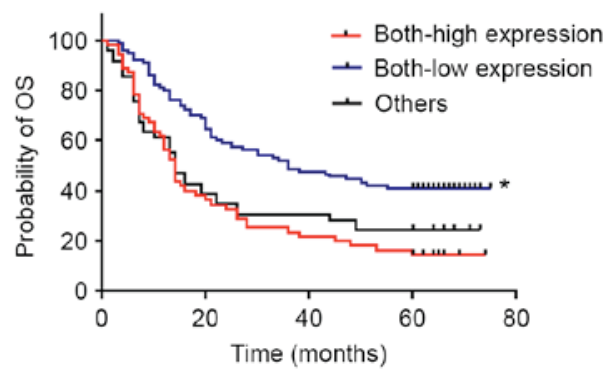

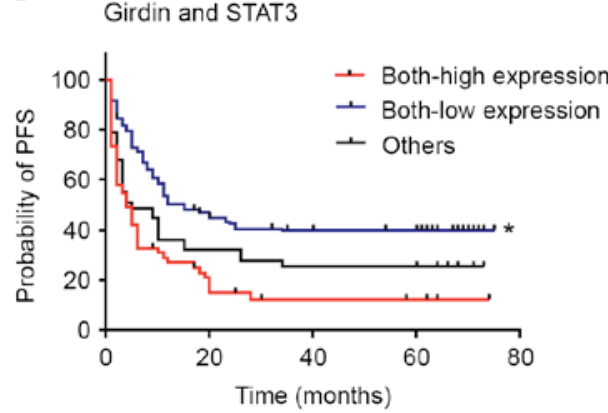

Figure 4. Kaplan-Meier survival curves of combined Girdin and STAT3 expression for OS and PFS in patients with non-small cell lung cancer. (A) Patients with low expression of both Girdin and STAT3 were observed to have significantly longer median OS compared with others and high/high expression (35 vs. 14 vs. 14 months). (B) Patients with low expression of both Girdin and STAT3 were observed to have significantly longer median PFS compared with others and high/high expression (12 vs. 5 vs. 4 months). ${ }^{\text {P }}<0.001$ vs. both high expression and others. OS, overall survival; PFS, progression-free survival; STAT3, signal transducer and activator of transcription 3; others, low/high or high/low expression of Girdin and STAT3, respectively.

identified that TNM stage $(\mathrm{P}=0.002$ and $\mathrm{P}=0.001)$, lymph node metastasis $(\mathrm{P}=0.009$ and $\mathrm{P}=0.004)$, distant metastasis $(\mathrm{P}=0.048$ and $\mathrm{P}=0.001)$ and Girdin expression $(\mathrm{P}=0.004$ and $\mathrm{P}=0.001)$ were prognostic factors in NSCLC for OS and PFS, respectively (Table III).

\section{Discussion}

Currently, the expression status of Girdin protein and its prognostic value for lung cancer are unclear. In the present study, it was identified that Girdin expression is significantly associated with TNM stage and tumor metastasis in human lung cancer.

Girdin, which is phosphorylated following epidermal growth factor stimulation and is a novel Akt substrate, is essential for cell metastasis (20). It is an important factor for the leading edge of cell pseudopods involved in cell movement (21). A study by Garcia-Marcos et al (22) reported that the survival rate of patients with colon cancer and Girdin-positive expression was reduced compared with Girdin-negative expression. Girdin expression also predicted mortality risk, 
Table III. Multivariate survival analysis of OS and PFS in patients with non-small cell lung cancer $(\mathrm{n}=334)$.

\begin{tabular}{|c|c|c|c|c|c|c|}
\hline \multirow[b]{2}{*}{ Parameter } & \multicolumn{3}{|c|}{ OS } & \multicolumn{3}{|c|}{ PFS } \\
\hline & HR & $95 \% \mathrm{CI}$ & P-value & HR & $95 \%$ CI & P-value \\
\hline \multicolumn{7}{|l|}{ TNM stage } \\
\hline I-IIIA & 1.000 & & & 1.000 & & \\
\hline IIIB-IV & 0.490 & $0.316-0.757$ & 0.002 & 0.480 & $0.311-0.739$ & 0.001 \\
\hline \multicolumn{7}{|c|}{ Tumor stage } \\
\hline $\mathrm{T} 1$ & 1.000 & & & 1.000 & & \\
\hline $\mathrm{T} 2$ & 0.454 & $0.251-0.821$ & 0.009 & 0.449 & $0.249-0.810$ & 0.008 \\
\hline $\mathrm{T} 3$ & 0.901 & $0.544-1.491$ & 0.684 & 0.912 & $0.551-1.511$ & 0.722 \\
\hline $\mathrm{T} 4$ & 1.303 & $0.736-2.307$ & 0.363 & 1.780 & $1.009-3.141$ & 0.047 \\
\hline \multicolumn{7}{|c|}{ Lymph node metastasis } \\
\hline Yes & 1.000 & & & 1.000 & & \\
\hline No & 1.462 & $1.101-1.942$ & 0.009 & 1.505 & $1.139-1.989$ & 0.004 \\
\hline \multicolumn{7}{|c|}{ Distant metastasis } \\
\hline Yes & 1.000 & & & 1.000 & & \\
\hline No & 1.561 & $1.005-2.427$ & 0.048 & 2.116 & $1.355-3.311$ & 0.001 \\
\hline \multicolumn{7}{|c|}{ Girdin expression } \\
\hline Low & 1.000 & & & 1.000 & & \\
\hline High & 1.894 & $1.228-2.921$ & 0.004 & 2.127 & $1.366-3.311$ & 0.001 \\
\hline \multicolumn{7}{|c|}{ STAT3 expression } \\
\hline Low & 1.000 & & & 1.000 & & \\
\hline High & 0.796 & $0.527-1.202$ & 0.277 & 0.686 & $0.445-1.058$ & 0.088 \\
\hline
\end{tabular}

HR, hazard ratio; CI, confidence interval; OS, overall survival; PFS, progression-free survival; TNM, tumor/node/metastasis; STAT3, signal transducer and activator of transcription 3 .

independent of microsatellite stability status. The authors concluded that Girdin may serve as a convenient metastasis biomarker for colon cancer (22). In the present study, it was demonstrated that patients with elevated Girdin expression had poorer OS and PFS compared with those with lower expression levels. These results are consistent with previous investigations of Girdin in other cancer types. In breast cancer tissues and cell lines, Girdin was highly expressed, and the co-expression of Girdin and tumor necrosis factor receptor 4 led to an increased rate of lymph node metastasis (23). A study by Nishimae et al (24) reported that the expression of Girdin in invasive breast cancer was strongly associated with lymph node metastasis. In esophageal squamous cell carcinoma (ESCC), Girdin was demonstrated to be involved in the motility of ESCC cells, and the expression of Girdin protein was inversely correlated with ESCC patient survival (12). In the present study, it was identified that the expression rate of Girdin in NSCLC was $38.93 \%$, which differed from $72.2 \%(26 / 36)$ in a study by Song et al (13) of 36 NSCLC patients undergoing surgery. This difference may be because 334 patients with different stages were recruited to the present study, whereas only patients with early-stage disease were enrolled in the study by Song et al (13). The present study also demonstrated that tissues with stronger expression of Girdin were obtained from metastasis sites, which may be because Girdin facilitates cell invasion and metastasis.
STAT3 is a STAT family member activated by tyrosine phosphorylation in response to various factors, such as epidermal growth factor and IL-6 $(25,26)$. It was reported by Dunkel et al (16) that STAT3 protein upregulates Girdin expression, and that Girdin enhances STAT3 activation in a positive feedback loop during wound healing and tumor metastasis. STAT3 was also demonstrated to be essential for Girdin expression under stimulated tension force under physiological conditions, as well as for osteoblast proliferation and migration during quiescence (27). These findings suggest that STAT3/Girdin pathway activation has a critical role in proliferation and migration. In the present study, it was revealed that Girdin overexpression was correlated with STAT3 in patient tissues. The results indicated that patients with high-level expression of both Girdin and STAT3 had lower OS and PFS rates compared with low/high, high/low and low/low expression, which indicates that STAT3/Girdin may serve an essential role in malignant behavior in NSCLC.

In conclusion, the present data indicated that Girdin may be a biomarker for metastasis in patients with NSCLC. Combined Girdin and STAT3 expression could predict poor prognosis in patients with NSCLC.

\section{Acknowledgements}

The present study was supported by the Education Department Foundation of Heilongjiang Province (grant no. 12521313). 


\section{References}

1. Siegel RL, Miller KD and Jemal A: Cancer statistics, 2016. CA Cancer J Clin 66: 7-30, 2016.

2. Marx V: Tracking metastasis and tricking cancer. Nature 494: 133-136, 2013.

3. Cairns RA, Khokha R and Hill RP: Molecular mechanisms of tumor invasion and metastasis: An integrated view. Curr Mol Med 3: 659-671, 2003.

4. Cetin K, Ettinger DS, Hei YJ and O'Malley CD: Survival by histologic subtype in stage IV nonsmall cell lung cancer based on data from the surveillance, Epidemiology and end results program. Clin Epidemiol 3: 139-148, 2011.

5. Yang Y, Ahn YH, Chen Y, Tan X, Guo L, Gibbons DL, Ungewiss C, Peng DH, Liu X, Lin SH, et al: ZEB1 sensitizes lung adenocarcinoma to metastasis suppression by PI3K antagonism. J Clin Invest 124: 2696-2708, 2014

6. Enomoto A, Murakami H, Asai N, Morone N, Watanabe T, Kawai K, Murakumo Y, Usukura J, Kaibuchi K and Takahashi M: Akt/PKB regulates actin organization and cell motility via Girdin/APE. Dev Cell 9: 389-402, 2005.

7. Ohara K,Enomoto A,Kato T,Hashimoto T, Isotani-Sakakibara M, Asai N, Ishida-Takagishi M, Weng L, Nakayama M, Watanabe T, et al: Involvement of Girdin in the determination of cell polarity during cell migration. PLoS One 7: e36681, 2012

8. Ghosh P, Tie J, Muranyi A, Singh S, Brunhoeber P, Leith K, Bowermaster R, Liao Z, Zhu Y, LaFleur B, et al: Girdin (GIV) expression as a prognostic marker of recurrence in mismatch repair-proficient stage II colon cancer. Clin Cancer Res 22: 3488-3498, 2016.

9. Liu C, Zhang Y, Xu H, Zhang R, Li H, Lu P and Jin F: Girdin protein: A new potential distant metastasis predictor of breast cancer. Med Oncol 29: 1554-1560, 2012.

10. Peng WT, Hu X, Yao L, Jiang YZ and Shao ZM: Elevated expression of Girdin in the nucleus indicates worse prognosis for patients with estrogen receptor-positive breast cancer. Ann Surg Oncol 21 (Suppl 4): S648-S656, 2014.

11. Gu F, Wang L, He J, Liu X, Zhang H, Li W, Fu L and Ma Y: Girdin, an actin-binding protein, is critical for migration, adhesion, and invasion of human glioblastoma cells. J Neurochem 131: 457-469, 2014.

12. Shibata T, Matsuo Y, Shamoto T, Hirokawa T, Tsuboi K, Takahashi $\mathrm{H}$, Ishiguro $\mathrm{H}$, Kimura $\mathrm{M}$, Takeyama $\mathrm{H}$ and Inagaki $\mathrm{H}$ Girdin, a regulator of cell motility, is a potential prognostic marker for esophageal squamous cell carcinoma. Oncol Rep 29: 2127-2132, 2013

13. Song JY, Jiang P, Li N, Wang FH and Luo J: Clinical significance of Girdin expression detected by immunohistochemistry in non-small cell lung cancer. Oncol Lett 7: 337-341, 2014.

14. Buettner R, Mora LB and Jove R: Activated STAT signaling in human tumors provides novel molecular targets for therapeutic intervention. Clin Cancer Res 8: 945-954, 2002.

15. Lui GY, Kovacevic Z, V Menezes S, Kalinowski DS Merlot AM, Sahni S and Richardson DR: Novel thiosemicarbazones regulate the signal transducer and activator of transcription3 (STAT3) pathway: Inhibition of constitutive and interleukin 6-induced activation by iron depletion. Mol Pharmacol 87: 543-560, 2015.

16. Dunkel Y, Ong A, Notani D, Mittal Y, Lam M, Mi X and Ghosh P: STAT3 protein up-regulates $\mathrm{G} \alpha$-interacting vesicle-associated protein (GIV)/Girdin expression, and GIV enhances STAT3 activation in a positive feedback loop during wound healing and tumor invasion/metastasis. J Biol Chem 287: 41667-41683, 2012.
17. Pan B, Shen J, Cao J, Zhou Y, Shang L, Jin S, Cao S, Che D, Liu F and Yu Y: Interleukin-17 promotes angiogenesis by stimulating VEGF production of cancer cells viathe STAT3/GIV signaling pathway in non-small-cell lung cancer. Sci Rep 5: 16053, 2015.

18. Oken MM, Creech RH, Tormey DC, Horton J, Davis TE, McFadden ET and Carbone PP: Toxicity and response criteria of the eastern cooperative oncology group. Am J Clin Oncol 6: 649-655, 1982

19. Goldstraw P, Crowley J, Chansky K, Giroux DJ, Groome PA, Rami-Porta R, Postmus PE, Rusch V and Sobin L; International Association for the Study of Lung Cancer International Staging Committee; Participating Institutions: The IASLC lung cancer staging project: Proposals for the revision of the TNM stage groupings in the forthcoming (seventh) edition of the TNM Classification of malignant tumours. J Thorac Oncol 2: 706-714, 2007.

20. Omori K, Asai M, Kuga D, Ushida K, Izuchi T, Mii S, Enomoto A, Asai N, Nagino M and Takahashi M: Girdin is phosphorylated on tyrosine 1798 when associated with structures required for migration. Biochem Biophys Res Commun 485: 934-940, 2015

21. Garcia-Marcos M, Ghosh P and Farquhar MG: GIV/Girdin transmits signals from multiple receptors by triggering trimeric G protein activation. J Biol Chem 290: 6697-6704, 2015.

22. Garcia-Marcos M, Jung BH, Ear J, Cabrera B, Carethers JM and Ghosh P: Expression of GIV/Girdin, a metastasis-related protein, predicts patient survival in colon cancer. FASEB J 25: 590-599, 2011.

23. Wang A, Wang J, Sun L, Jin J, Ren H, Yang F, Diao K, Wei M and Mi X: Expression of tumor necrosis factor receptor-assicated factor 4 correlates with expression of Girdin and promotes nuclear translocation of Girdin in breast cancer. Mol Med Rep 11: 3635-3641, 2015

24. Nishimae K, Tsunoda N, Yokoyama Y, Kokuryo T, Iwakoshi A, Takahashi $\mathrm{M}$ and Nagino M: The impact of Girdin expression on recurrence-free survival in patients with luminal-type breast cancer. Breast Cancer 22: 445-451, 2015.

25. Yue P,Zhang X, Paladino D, Sengupta B, Ahmad S, Holloway RW, Ingersoll SB and Turkson J: Hyperactive EGF receptor, Jaks and Stat 3 signaling promote enhanced colony-forming ability, motility and migration of cisplatin-resistant ovarian cancer cells. Oncogene 31: 2309-2322, 2012.

26. Sun F, Zhang ZW, Tan EM, Lim ZLR, Li Y, Wang XC, Chua SE, Li J, Cheung E and Yong EL: Icaritin suppresses development of neuroendocrine differentiation of prostate cancer through inhibition of IL-6/STAT3 and Aurora kinase a pathways in TRAMP mice. Carcinogenesis 37: 701-711, 2016.

27. Hu JT, Li Y, Yu B, Gao GJ, Zhou T and Li S: Girdin/GIV is upregulated by cyclic tension, propagates mechanical signal transduction, and is required for the cellular proliferation and migration of MG-63 cells. Biochem Biophys Res Commun 464: 493-499, 2015

(i) $($ ) This work is licensed under a Creative Commons cc) $\mathrm{EY}$ NO NO Attribution-NonCommercial-NoDerivatives 4.0 International (CC BY-NC-ND 4.0) License. 